\title{
The role of surface charge in cellular uptake and cytotoxicity of medical nanoparticles
}

\author{
This article was published in the following Dove Press journal: \\ International Journal of Nanomedicine \\ 31 October 2012 \\ Number of times this article has been viewed
}

\section{Eleonore Fröhlich}

Center for Medical Research, Medical University of Graz, Graz, Austria

Correspondence: Eleonore Fröhlich Center for Medical Research, Medical University of Graz, Stiftingtalstr 24,

Graz A-8010, Austria

$\mathrm{Tel}+433163857301 \mathrm{I}$

Fax +43 31638573009

Email eleonore.froehlich@medunigraz.at
Abstract: Many types of nanoparticles (NPs) are tested for use in medical products, particularly in imaging and gene and drug delivery. For these applications, cellular uptake is usually a prerequisite and is governed in addition to size by surface characteristics such as hydrophobicity and charge. Although positive charge appears to improve the efficacy of imaging, gene transfer, and drug delivery, a higher cytotoxicity of such constructs has been reported. This review summarizes findings on the role of surface charge on cytotoxicity in general, action on specific cellular targets, modes of toxic action, cellular uptake, and intracellular localization of NPs. Effects of serum and intercell type differences are addressed. Cationic NPs cause more pronounced disruption of plasma-membrane integrity, stronger mitochondrial and lysosomal damage, and a higher number of autophagosomes than anionic NPs. In general, nonphagocytic cells ingest cationic NPs to a higher extent, but charge density and hydrophobicity are equally important; phagocytic cells preferentially take up anionic NPs. Cells do not use different uptake routes for cationic and anionic NPs, but high uptake rates are usually linked to greater biological effects. The different uptake preferences of phagocytic and nonphagocytic cells for cationic and anionic NPs may influence the efficacy and selectivity of NPs for drug delivery and imaging.

Keywords: endocytosis, plasma membrane, lysosomes, polystyrene particles, quantum dots, dendrimers

\section{Introduction}

Nanoparticles (NPs) can be applied in the medical sector as sensors, in cell and organ imaging, drug delivery, implants, and implant coatings. Surface charge is the most important factor affecting NPs in terms of their function in imaging and drug delivery. In these applications, inorganic carbon, metal, metal oxides, and sulfides as well as a variety of organic and biodegradable NPs were used (Table 1). Many NPs are tested in preclinical studies, but only polymer-based, lipid-based, protein-based NPs and nanocrystals are approved for drug delivery, while iron oxide NPs are in clinical use for magnetic resonance imaging and drug delivery. Most approved NP formulations are formulations of conventional compounds for improved drug delivery, particularly in oncology.

Reasons for the relatively low number of approved particles are, among others, problems in reproducibility and long-term stability of NP formulations and lack of guidelines for relevant biological testing. The attachment of functional groups and coatings to prevent uptake by the reticuloendothelial system increases the variety of NP preparations. As each parameter can be varied, a great number of NPs could be designed. For a faster development of efficient particles, it would be very useful to 


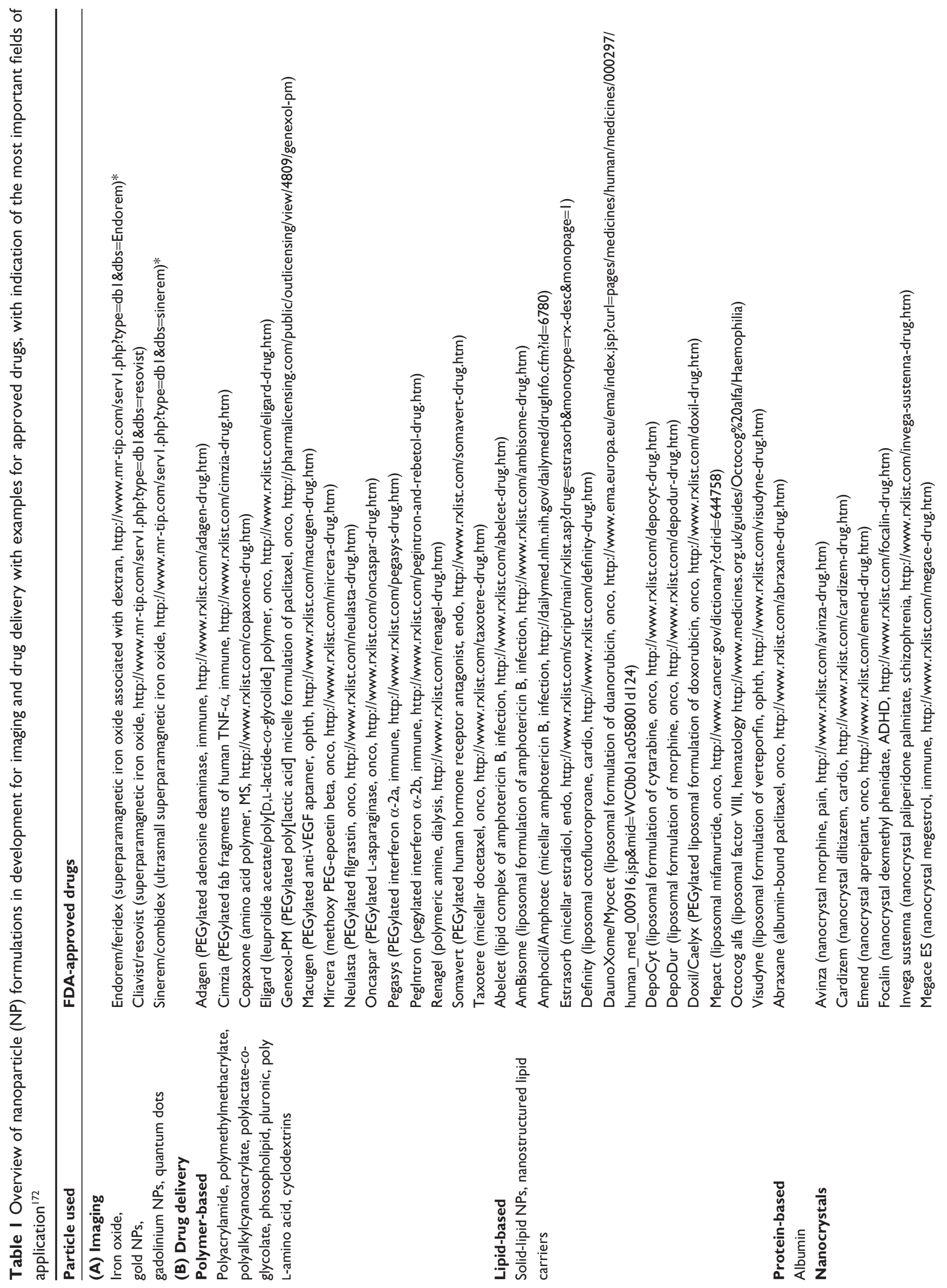



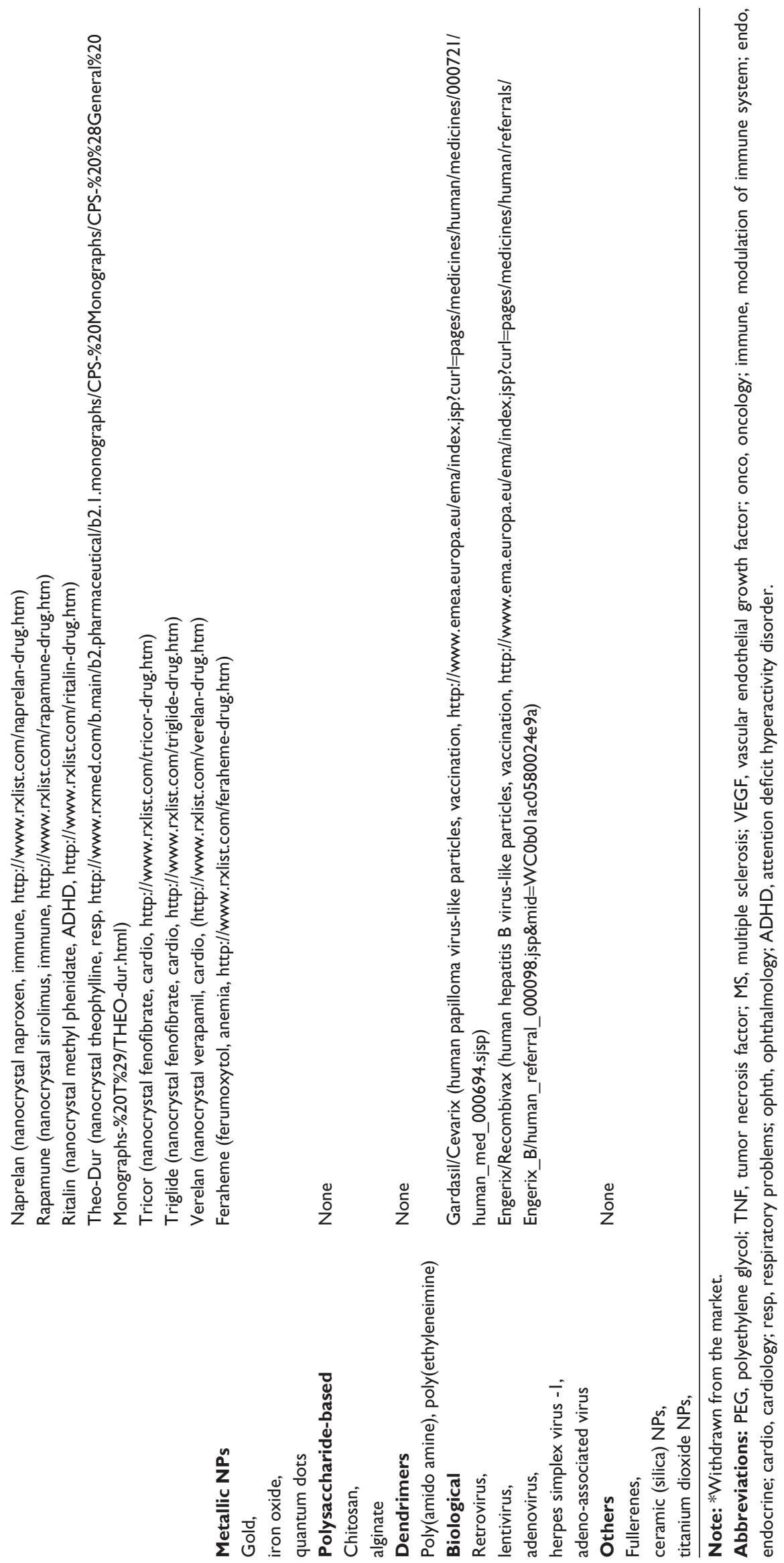
identify correlations of specific surface properties to cellular effects. Studies on polystyrene particles, where size and charge can be changed in a controlled way, have been widely used as models.

Positively charged constructs are used in nonviral gene transfection, and studies on gene-delivery systems with cationic liposomes and cationic polymers help to understand the role of positive surface charge. Cationic lipid/DNA complexes (lipoplexes) enter cells by endocytosis or direct penetration through the cell membrane after interaction of the cationic lipopolyamines with proteoglycans of the cell membrane. For subsequent delivery of DNA to the nucleus, degradation in the lysosomes is prevented by different mechanisms. Lipoplexes have protonable amine groups that slow down the acidification of endosomes, and thereby slow down endosome-lysosome transition. ${ }^{1} \mathrm{Xu}$ and Szoka ${ }^{2}$ proposed the following mode of action: anionic lipids from the cytoplasmic facing monolayer of the endosome flip-flop in the membrane and diffuse laterally to form charge neutral ion pairs with the lipoplexes. Thereby, the DNA is released from the lipoplex and from the endosome. The mechanism of gene delivery by cationic polymers (polyplexes) is slightly different. Cationic polymers form complexes with the negatively charged DNA, and still possessing a net positive surface charge, bind to the negatively charged plasma membrane of the target cells to a higher degree than negatively charged or neutral molecules. ${ }^{3}$ For release of the genetic material, these complexes are transported via the endosomal-lysosomal system into the endosomes where these complexes are cleaved by enzymes into polyamines and DNA. The polyamines buffer $\mathrm{H}^{+}$and cause lysosomal $\mathrm{Cl}$ accumulation with subsequent osmotic swelling and lysis of the endosomes, thereby preventing degradation of the DNA by lysosomal nucleases. This mechanism is termed the "proton sponge" effect. The released DNA passes to the nucleus and integrates into the nuclear DNA.

The use of cationic NPs is limited by their cytotoxicity. For poly(propylene imine) dendrimers, other candidates for nonviral gene transfer, the relation of primary amine groups and toxicity has been clearly shown. ${ }^{4}$ Shielding of the amine groups by functionalization decreased the toxicity of these constructs. ${ }^{5}$ This review aims to clarify if cationic NPs interact with other cellular targets, act by other cytotoxic mechanisms and use other uptake routes than anionic and neutral NPs.

\section{Cytotoxicity}

The cytotoxicity of NPs depends on particle parameters like morphology, such as aspect ratio/shape and size.
Hydrophobicity, surface area in terms of roughness and porosity, and surface charge influence the capacity to produce reactive oxygen species (ROS), determine binding sites for receptors, and influence dispersion and aggregation of the particles. Cytotoxicity is also often due to contamination, solubility and release of toxic components, and adsorption of compounds. On the other hand, biological parameters such as cell type used for the study or the culture and exposure conditions (eg, cell density, particle concentration, medium composition, temperature), also influence cytotoxicity.

Main influencing factors for cytotoxicity are material, size, shape, composition, surface charge, and surface hydrophobicity. The correlation of cytotoxic effect and size has been studied in many papers. For nonphagocytic cells, small size correlates with increased cytotoxicity. In vitro experiments showed higher cytotoxicity of well-dispersed mesoporous silica and amorphous silica, dolomite, $\mathrm{ZnO}$, $\mathrm{Ni}, \mathrm{Ag}$, and polystyrene NPs compared to the respective microparticles. ${ }^{6-15}$ When particles smaller than $100 \mathrm{~nm}$ are compared, still-smaller particles act more toxically than larger ones (quantum dots, ${ }^{16} \mathrm{TiO}_{2}{ }^{17}$ ). In contrast to these studies, no differences have been reported for $10-100 \mathrm{~nm}$ silica particles compared to $45 \mu \mathrm{m}$ ones, ${ }^{18}$ and for nickel ferrite NPs. ${ }^{19}$ Okuda-Shimazaki et al demonstrated the importance of the aggregation state and showed that larger aggregates of $\mathrm{TiO}_{2}$ NPs acted more cytotoxically than smaller ones. ${ }^{20}$

Phagocytes such as macrophages and monocytes react more strongly to microparticles than to NPs. One study reported higher cell damage for silica microparticles than for NPs, ${ }^{21}$ and another study noticed absence of cell damage in THP-1 cells for 30-70 nm silica NPs, while $1000 \mathrm{~nm}$ particles acted cytotoxically. ${ }^{22}$

Compared to nonphagocytic cells, THP-1 cells are also much more resistant to $20-200 \mathrm{~nm}$ silver and to $21 \mathrm{~nm}$ $\mathrm{TiO}_{2} \mathrm{NPs} .{ }^{23}$ Size-dependent toxicity studies in vivo are less conclusive: systemic toxicity upon intraperitoneal application of $10 \mathrm{~nm}$ and $50 \mathrm{~nm}$ iron oxide particles was higher than that after dosing with $1000 \mathrm{~nm}$ particles. ${ }^{24}$ When applied intraocularly however, $4000 \mathrm{~nm}$ magnetic iron oxide particles caused more toxicity than $50 \mathrm{~nm}$ particles. ${ }^{25}$

It is also generally accepted that fiber-shaped NPs of a given material are more reactive and toxic compared with spherical particles: carbon nanotubes, for instance, are generally more toxic than fullerenes. ${ }^{26,27}$ Hydrophobicity is often linked to surface charge, but at the same surface charge, NPs with hydrophobic surfaces, eg, oleic acid-coated nickel ferrite and stearic acid-coated $\mathrm{TiO}_{2}$ particles reacted more cytotoxically than the respective noncoated particles. ${ }^{19,28}$ 
In the following sections, the influence of charge on cytotoxicity and cellular uptake will be described in more detail.

\section{Charge-dependent cytotoxicity}

For cytotoxic action, both charge density and charge polarity play a role. Charged NPs, eg, gold particles, are more cytotoxic than neutral forms, ${ }^{29}$ and positively charged $\mathrm{ZnO}$, silica, silica-titania hollow, and gold nanoparticles act more cytotoxically than negative variants of similar size in nonphagocytic cells. ${ }^{30-34}$ Cytotoxic action of poly(amidoamine) (PAMAM) dendrimers is correlated with the number of primary amino groups,${ }^{35}$ and cytotoxicity of PAMAM dendrimers decreased when amine groups were neutralized with acetyl groups. ${ }^{36}$ Also, in in vivo experiments, high numbers of primary amine groups increased the toxicity of dendrimers. ${ }^{37}$ This rule, however, does not apply to all NPs. For some NPs, eg, poly(lactic-co-glycolic acid) (PLGA) particles, charge appears to play no role, ${ }^{38}$ or other parameters, eg, porosity for mesoporous $\mathrm{SiO}_{2}$ particles, are more important than surface charge. ${ }^{39}$ The lack of negative effects of positively charged PLGA particles could be due to the use of chitosan, a polysaccharide with excellent biological properties, as coating material. ${ }^{38}$ Shielding of cationic groups by functionalization and polethylene glycol (PEG)ylation decreased both cytotoxicity and efficacy in NPs where efficacy and cytotoxicity were linked to cationic charge. ${ }^{40}$
In contrast to nonphagocytic cells, phagocytic cells preferentially interact with negatively charged particles, presumably due to the ingestion of bacteria, which also displays a net negative charge. ${ }^{41}$ The stronger interaction of phagocytes with negatively charged particles may be the reason for the higher cytotoxicity of anionic cyanoacrylic NPs compared to cationic ones. ${ }^{42}$ In line with the low importance of cationic charge for macrophage uptake and cytotoxicity, shielding of the positive surface charge by PEGylation displayed only a small effect on cellular uptake and cytotoxicity in these cells, whereas marked decrease in membrane damage, lipid peroxidation, and oxidative stress were seen in nonphagocytic neuroblastoma cells. ${ }^{43}$ It would, however, be oversimplistic to explain these effects only by neutralization of the surface charge, because both functionalization and coating also markedly increase particle size, another key parameter for NP cytotoxicity. Conclusions on surface-charge effects, therefore, are only valid when comparing functionalized or nonfunctionalized particles of similar sizes. When comparing functionalized PLGA NPs with different coatings for tumor targeting, the cationic NPs were slightly more effective than anionic ones, and both accumulated to a higher extent in tumor tissue than bare Pluronic-coated ones. ${ }^{44}$

In general, NPs may interact with a variety of cellular targets to cause adverse effects (Figure 1).

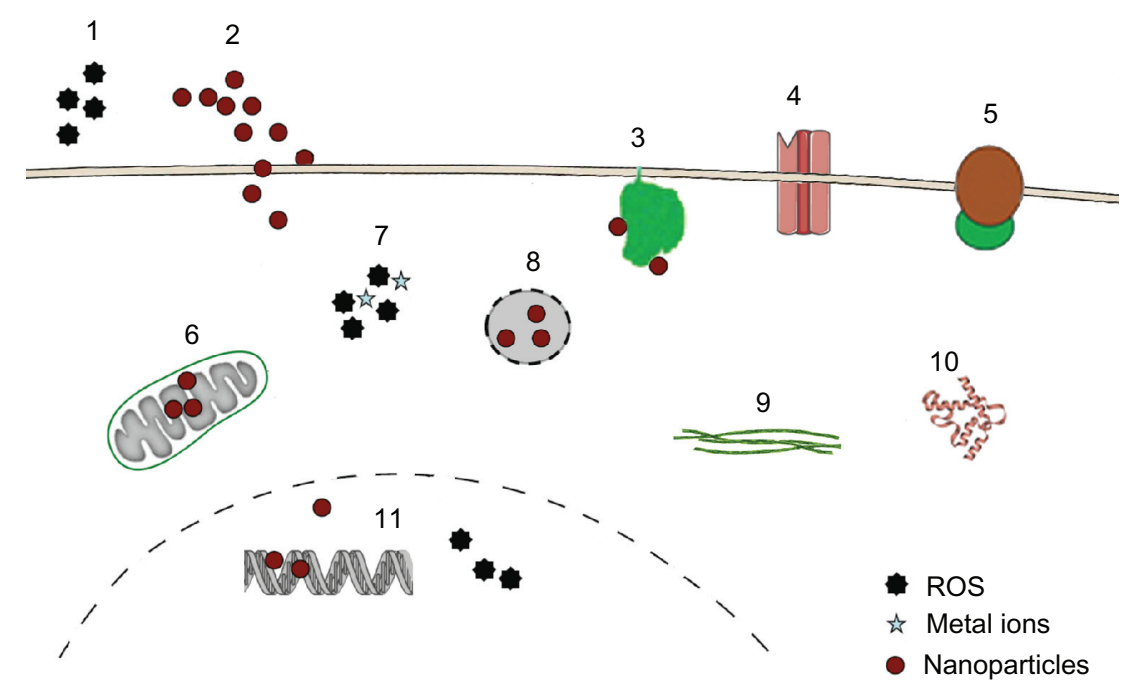

Figure I Targets for cytotoxicity of nanoparticles (NPs).

Notes: NPs may act through extracellular generation of reactive oxygen species (ROS) (I), they may physically damage the plasma membrane by causing holes (2) or bind to membrane proteins like nicotinamide adenine dinucleotide phosphate-oxidase (3), $\mathrm{Ca}^{2+}$ channels (4), and membrane receptors (5), thereby inducing oxidative signaling, increasing intracellular $\mathrm{Ca}^{2+}$ levels and activating second-messenger cascades. Inside the cells, NPs may interfere with mitochondrial metabolism (6), causing generation of radicals and induction of apoptosis. Intracellular ROS generation by NPs or by metals from lysosomal degradation (7) as well as lysosomal disruption (8) and direct binding to components of the cytoskeleton (9) and the induction of structural alterations of proteins (10) are additional modes of toxic actions. In the nucleus, interference with the transcription machinery and oxidative damage of the DNA (II) may occur. 


\section{Plasma membrane}

NPs may cause focal dissolution of the plasma membrane and hole formation and perturbation of the internal membrane structure. Focal dissolution by carbon particles and loss of membrane folds induced by brookite NPs in exposed cells were observed by electron microscopy. ${ }^{45,46}$ Plasma-membrane folds in Madin-Darby canine kidney cells (MDCK) disappeared upon exposure to brookite NPs. ${ }^{46}$ The authors speculated that generation of ROS induced lipid peroxide formation in the membranes, thereby decreasing their flexibility. Wang et al, ${ }^{47}$ by contrast, showed passive penetration of quantum dots by increasing membrane fluidity. These effects, however, do not inevitably lead to cell death. To repair plasma-membrane damage, either by pore formation through endogenous factors (complement, perforin) or by exogenous factors (bacterial toxins), cells possess several repair mechanisms. Disruption of membrane integrity leads to influx of $\mathrm{Ca}^{2+}$ and can be repaired by exocytosis of internal membranes, endocytosis of the permeabilized site, and shedding of the injured membrane through microparticle formation. ${ }^{48}$ Repair of the membrane occurs within seconds, and the remodeling of the cortical actin takes a few minutes. ${ }^{49}$

Electrophysiological measurements and studies with unilamellar lipid vesicles indicated the transient disruption of plasma-membrane integrity upon the passive entry of silica NPs into cells..$^{50,51}$ Pores $<1 \mu \mathrm{m}$ in diameter can be closed by sealing the plasma membrane around the hole, and it is likely that plasma-membrane damage by NPs that led to decreased viability exceeded the repair capacity of the cells.

To get insight into the molecular mechanism of plasmamembrane damage, several groups used supported lipid bilayers. $^{52,53}$ 1,2-Dimyristoyl-sn-glycero-3-phosphocholine (DMPC) lipid bilayers supported on solid substrates do not exactly represent the composition of the plasma membrane in vivo, because they usually consist of only one type of lipid and lack the asymmetric distribution of the lipids and the presence of proteins in real plasma membranes, but they can mimic mechanical processes and metabolism of the plasma membrane quite well.

Using bilayer models and computer models of DMPC, the influence of size and surface charge on the interaction with lipids and hole formation was studied and several mechanisms identified. ${ }^{54}$ Large cationic G7 PAMAM dendrimers were able to cause holes in intact bilayers, whereas the smaller cationic G5 dendrimers increased the size of preexisting holes but did not generate new holes. Neutral dendrimers adsorbed to the edges of preexisting holes, ${ }^{55}$ and removed lipids from the edge of the hole, and formed dendrimer-lipid aggregates. ${ }^{56}$
According to Lin et al, cationic gold particles $(2.2 \mathrm{~nm})$ can disrupt $20 \times 20 \mathrm{~nm}$ lipid bilayers but not $28 \times 28 \mathrm{~nm}$ lipid bilayers. ${ }^{53}$ The capacity for hole formation was influenced by the density of the particle's cationic charge, the negativity of the lipid bilayer, surface tension, temperature, and salt concentration. Simulation using coarse-grained representations suggests that the degree of gold particle-cell interaction can be tuned by variation of the surface charge. Strongly cationic particles create defective areas across the entire surface of the outer leaflet of the bilayer, and a hydrophilic pore with highly disordered lipids at the edge is formed..$^{52}$ In these models, cationic NPs could penetrate better through plasma membranes than anionic particles.

NPs can also cause effects at the plasma membrane by interaction with membrane-bound proteins. Binding to nicotinamide adenine dinucleotide phosphate-oxidase leads to generation of $\mathrm{ROS},{ }^{57}$ activation of voltage-gated $\mathrm{Ca}^{2+}$ channels to intracellular $\mathrm{Ca}^{2+}$ changes,${ }^{58}$ and the activation of membrane receptors to activation of the second-messenger pathways. ${ }^{59,60}$ Binding to membrane receptors is intended for therapeutic interventions, eg, the binding of human epidermal growth-factor receptor 2 (HER2)-coated NPs in diagnosis and treatment of HER2 high-expressing breast carcinoma cells. ${ }^{61}$ Also, uncoated, nontargeted NPs bind to epithelial growth factor receptor and $\beta 1$ integrin receptors and activate the respective signaling pathways. ${ }^{62}$

Intracellular targets of NPs are mitochondria, lysosomes, nucleus, and intracellular proteins.

\section{Mitochondria}

Swelling of mitochondria occurred after cellular exposure to quantum dots ${ }^{63}$ and decrease of the mitochondrial membrane potential has been reported for silver, $\mathrm{TiO}_{2}$ and alumina NPs. ${ }^{6466}$ The increase in mitochondrial membrane permeability was induced either by disruption of the respiratory chain or by changes in Bax and Bcl-2 expression, which lead to disruption of mitochondrial metabolism, increased ROS production, adenosine diphosphate-induced depolarization, release of cytochrome $\mathrm{C}$, and induction of apoptosis. ${ }^{67,68}$ Whereas no obvious morphological damage of lysosomes and mitochondria was reported for carboxyl polystyrene particles of different sizes, ${ }^{10}$ amine-functionalized polystyrene particles damaged mitochondria and lysosomes in astrocytoma cells. ${ }^{69}$

\section{Lysosomes}

Lysosomes are likely targets for ROS-producing NPs because they are very sensitive to oxidative stress. ${ }^{70}$ Healthy lysosomes 
may increase the cytotoxicity of NPs by the release of leachable metal ions (eg, from iron oxide $\mathrm{NPs}^{71}$ ), which then generate cellular oxidative stress. Lysosomes as targets for cytotoxicity have been revealed for quantum dots and silicon NPs. Costaining with lysosome markers revealed swollen lysosomes upon exposure to quantum dots. ${ }^{72}$ Other groups reported morphological alterations upon exposure to cationic polystyrene particles ${ }^{69}$ and cytotoxicity of silicon NPs caused by permeabilization of lysosomes. ${ }^{73}$ Especially for cationic NPs and polymers, swelling and disruption of lysosomes due to buffering of $\mathrm{H}^{+}$is a major mode of cytotoxic action. ${ }^{74}$ When lysosomal membranes are damaged, a high amount of hydrolytic enzymes is released, leading to degradation of intracellular macromolecules. Independent from the release of hydrolytic enzymes, a correlation of cytotoxicity and lysosomal localization has been described for $\mathrm{CeO}_{2}$ NPs. ${ }^{75}$ Anionic $\mathrm{CeO}_{2}$ NPs were taken up into lysosomes and caused cell death, whereas cationic NPs were localized in the cytoplasm of viable tumor cells. The extent of cellular uptake was not correlated with this cytotoxicity, and it was not clear from this study how lysosomal localization was linked to cytotoxicity.

Autophagy, the intracellular disposal mechanism to remove and degrade undesirable substances, can be activated by cellular stress. The cellular amount of autophagosomes upon exposure to gold NPs, iron oxide NPs, fullerenes, carbon nanotubes, and quantum dots was increased due to oxidative stress, disruption of cytoskeleton, and mitochondrial damage. ${ }^{76-79}$ In the absence of metals, either as an integrative part of the particles or as contamination, accumulation of autophagosomes has only been reported in cells exposed to NPs with positive surface charge, cationic polymeric NPs, polyplexes, and cationic dendrimers, and not for anionic NPs. ${ }^{80-82}$

\section{Nucleus}

NPs may inhibit cell division and arrest cytokinesis, an action often seen in combination with other effects on DNA. Many NPs $(<50 \mathrm{~nm})$ can get into the nucleus, ${ }^{67,83}$ but localization in the nucleus is not a prerequisite for action on the DNA because intracellular NPs can gain access to the genetic material during mitosis when the nuclear membrane breaks down. In earlier descriptions of the nuclear pores, passage of particles as large as $25 \mathrm{~nm}$ has been reported.$^{84}$ Later studies report the nuclear pore as an hourglass-like channel with a diameter of 45-70 nm. ${ }^{85}$ In both studies, the dynamic size of the pore was mentioned, which also allows the entry of larger $(90 \mathrm{~nm})$ nuclear-targeted NPs into the nucleus. ${ }^{86}$ The access to the nucleus, in addition to size, depends on surface charge: noncharged silica NPs can enter the nucleus, whereas the same particles are retained in the cytoplasma when they are functionalized with amine or carboxyl groups. ${ }^{87}$

Studies on isolated DNA revealed thermal stabilization by cationic but not by anionic poly(L-lysine) NPs. ${ }^{88}$ This interaction may present a mechanical obstacle to polymerase motion along the DNA chain, leading to inhibition of transcription. ${ }^{89}$ Also, aberrant clusters of topoisomerase I induced by $\mathrm{SiO}_{2}$ NPs can cause alterations in DNA transcription. ${ }^{90}$ Genotoxic effects by NPs occur either directly or by oxidative damage of DNA. The consequences of ROS in the nucleus are point mutations in the DNA and double-strand breaks, which have been accused of causing alterations of DNA structure, mitosis, and transcription. High surface activity in the form of ROS generation or through $\mathrm{Ti}-\mathrm{O}$ or $\mathrm{Ti}-\mathrm{N}$ bonds could cause DNA alterations induced by $\mathrm{Ag}$ and $\mathrm{TiO}_{2} \mathrm{NPs}^{67,91}$ Neither cationic nor anionic polystyrene particles interacted with chromosome reorganization. ${ }^{92}$ Extranuclear inhibition of translation can occur through interference of NPs with mRNA-stabilizing proteins.

\section{Intracellular proteins}

NPs have a high affinity to macromolecules, particularly to proteins. This binding may increase protein stability, decrease it and interfere with protein function, or have no effect on the protein..$^{93}$ Intracellular $\mathrm{TiO}_{2} \mathrm{NPs}$ induced conformational changes in tubulin and inhibited tubulin polymerization, ${ }^{94}$ and thereby could impair cell division, cellular transport, and cell migration. NPs such as $\mathrm{CeO}_{2}$, quantum dots, copolymer particles, and carbon nanotubes may also lead to protein aggregation and fibrillation. ${ }^{95}$ The formation of protein aggregates may promote the development of several neurodegenerative diseases like Alzheimer's disease, Parkinson's disease, Huntington's disease, amyotrophic lateral sclerosis, and prion diseases. Fullerenes, polymeric NPs, and quantum dots have also been reported to prevent the formation of protein aggregates in diseases like Alzheimer's, and potentially could be useful for the prevention of these diseases. ${ }^{96-98}$

Dendrimers, carbon nanotubes, alumina NPs, and chitosan NPs modulate the architecture of intercellular tight junctions by disruption and thereby decrease the transepithelial electrical resistance of cell monolayers. ${ }^{64,99-101}$ Lipid NPs do not affect tight junction proteins, and silver NPs increase the barrier function of endothelial monolayers. ${ }^{102,103}$ The role of surface charge on these effects is largely unknown.

The different sensitivity of plasma membrane and intracellular organelles to NPs' surface charge may lead to chargedependent modes of cytotoxicity. On this topic, however, few studies are available. 


\section{Charge-dependent differences in the mode of cytotoxic action}

It appears that positively charged NPs either directly or by detachment of adsorbed polymers (eg, polyethylenimine) cause membrane damage, whereas anionic particles cause intracellular damage. Although the mechanism of damage by anionic particles is not clear, a correlation of lysosomal localization and cytotoxicity has been identified for nanoceria particles. ${ }^{75}$ In one study, where variations of size $(30 \mathrm{~nm}$, $150 \mathrm{~nm}, 500 \mathrm{~nm}$ ) and surface charge (cationic, anionic, neutral) were evaluated, the relation of surface charge to cytotoxicity was more complex. In the $30 \mathrm{~nm}$ and $500 \mathrm{~nm}$ zeolite particles, surface charge had only a small effect on cytotoxicity, but marked differences between positively and negatively charged $150 \mathrm{~nm}$ zeolite particles were seen in epithelial (human embryonic kidney cells). ${ }^{104}$ This may be due to the fact that $150 \mathrm{~nm}$ particles possessed the highest charge densities. Amine-functionalized NPs acted more by disruption of membrane integrity, whereas carboxylfunctionalized ones induced apoptosis to a greater extent. In macrophages (RAW cells); however, the $150 \mathrm{~nm}$ carboxylfunctionalized particles showed more membrane disruption and more apoptosis than the ones with amine and thiol surface functionalization, corroborating the specific role of anionic charge for macrophages.

\section{Serum effects}

Coating with bovine serum albumin (BSA) or the presence of serum in the incubation medium reduced cytotoxicity for many NPs. Polystyrene particles, PLGA particles, polysaccharide NPs, and iron oxide NPs acted less cytotoxically on nonphagocytic cells in the presence of serum. . $^{3,9,105,106}$ Particularly, serum reduces the effects on membrane integrity. Potential causes for the mitigating effect of protein include instability of the suspension in the presence of proteins and masking of the reactive surface of the NPs, avoiding the interaction of the NPs with the plasma membrane and the generation of ROS. The decreased cytotoxicity in the presence of serum was usually correlated with a lower cellular uptake. ${ }^{105}$ In phagocytic cells, where increased cytotoxicity in the presence of serum was reported, ${ }^{107}$ serum coating is known to increase the cellular uptake of particles. ${ }^{108}$

\section{Cellular uptake}

Similar to cytotoxicity, cellular uptake is influenced by size, shape, material, surface charge, and surface hydrophobicity. Nonphagocytic cells take up spherical NPs between 20 and $50 \mathrm{~nm}$ at the highest rates. ${ }^{61,109-112}$ Enterocytes are an exception to this rule, because they preferentially ingest particles in the range between 100 and $200 \mathrm{~nm} .{ }^{113}$ Phagocytic cells, by contrast, preferentially ingest particles between 2 and $3 \mu \mathrm{m},{ }^{114}$ and phagocytose NPs to a lower extent. Phagocytes contain a higher amount of small supermagnetic iron oxide particles than of ultrasmall supermagnetic iron oxide particles, ${ }^{115}$ and they phagocytose particles $<300 \mathrm{~nm}$ less well than $5 \mu \mathrm{m}$ particles. ${ }^{116}$ Well-dispersed 20-200 nm silver particles are taken up by phagocytic (THP-1) cells to a lower degree than by nonphagocytic (A549 and HepG2) cells. ${ }^{23}$ Aggregates of silver NPs, however, are taken up by phagocytes to a higher extent. ${ }^{117}$

For iron oxide particles, size appears to be a stronger determinant for uptake than surface charge. ${ }^{118}$

\section{Charge-dependent cellular uptake and intracellular localization}

Studies on the effect of charge density and of the kind of charge (positive, negative) in nonphagocytic cells showed that charged polystyrene and iron oxide particles are taken up better than their uncharged counterparts. ${ }^{119-121}$ When charged groups on the surface were present, positively charged particles were generally better taken up than negatively charged ones. Cells ingest positively charged gold and silver particles, superparamagnetic iron oxide particles, hydroxylapatite, silicon dioxide, lipid particles, poly(lactic acid), chitosan, polymeric particles, and polystyrene particles to a higher extent than the respective anionic ones..$^{122-131}$

Lunov et al studied the preferential uptake of anionic particles by phagocytic cells in more detail. ${ }^{132}$ They compared the uptake of polystyrene particles in differentiated macrophages to that of monocytes and observed a preferential uptake of the carboxylated particles by macrophages and a higher uptake of amino-functionalized particles in monocytes. Macrophages have a higher phagocytic activity towards many bacteria than monocytes, ${ }^{133}$ and if the preference for anionic particles is linked to phagocytic activity, are expected to display a greater uptake than the less phagocytic monocytes.

The role of surface charge of polystyrene particles and quantum dots on cellular uptake is controversial. Carboxylated $1 \mu \mathrm{m}$ and $50 \mathrm{~nm}$ polystyrene particles were ingested to a higher degree by alveolar type I cells, ${ }^{134}$ whereas Fazlollahi et a $1^{135}$ showed preferential uptake of cationic polystyrene particles in MDCK cells. For quantum dots, some groups reported preferential uptake of anionic quantum dots, ${ }^{136,137}$ and others that of positively charged quantum dots. ${ }^{138}$ RymanRasmussen et $\mathrm{al}^{139}$ did not find any differences between the uptakes of positively and negatively charged quantum dots. 
Different degrees of hydrophobicity of the functionalized particles may be one reason for the disparate results. Bu et al also assessed the surface hydrophobicity of the quantum dots they used and speculated that the increased uptake of anionic particles may be caused by a higher hydrophobicity of these particles compared to the corresponding neutral and positive ones. ${ }^{140}$ When studying the uptake of polystyrene particles in alveolar macrophages, Makino et al suggested that the preference of cells to ingest charged particles in their study could also be due to the greater softness of amine and carboxylfunctionalized particles compared to plain ones. ${ }^{141}$

\section{Serum effects}

Both positively and negatively charged NPs bind serum and albumin, but coverage differs between the particles. The change-dependent coverage of carboxylated polystyrene particles with serum was higher than that of positively charged ones, ${ }^{142}$ whereas positively charged $\mathrm{CeO}$ particles bound BSA better than negatively charged ones. ${ }^{143}$ Similarly, reports on the effect of BSA and serum on cellular uptake showed controversial findings: cells ingested BSA precoated NPs to a lower degree than uncoated ones, as reported by Baier et al, ${ }^{105}$ but absorbed serum-coated cationic $\mathrm{CeO}$ and mesoporous silicon particles to a higher extent, according to data from other groups. ${ }^{142,144}$

\section{Mechanisms of cellular entry}

Under physiological conditions, NPs may enter the cells via passive and active transport. Passive transport of NPs into cells is relatively rare (eg, gold particles ${ }^{52,145}$ ), and most NPs enter cells by endocytosis. The mechanisms for passive uptake have only partly been identified. Arviso et al suggested perturbation of the membrane potential by positively charged gold particles with flipping of membrane areas as the mode of uptake. ${ }^{146}$ An orderly arrangement of hydrophilic and hydrophobic ligands at the particle surface facilitates passive entry for gold NPs and lipid particles. When the ligands were arranged as stripes, the particles were able to translocate easily across the membrane, while in the random arrangement endocytosis occurred. ${ }^{147-149}$

Endocytosis serves to absorb molecules from the extracellular space by invagination of the plasma membrane and formation of intracellular vesicles. The first type of endocytosis discovered was clathrin-mediated endocytosis, but in the meantime several additional types of endocytosis have been identified. For the study of NPs, in general, a simplified classification into the four routes of clathrin-mediated endocytosis, caveolae-mediated endocytosis, macropinocytosis, and clathrin-independent and caveolae-independent pathways is used $^{150-153}$ (Figure 2, adapted from Perez-Martinez et al ${ }^{154}$ ).

The endocytic routes described so far are receptormediated and transport with high efficiency. Bulk flow of substances from the extracellular space, by contrast, occurs through fluid-phase endocytosis, formerly termed pinocytosis. ${ }^{155}$ This transport is nonsaturable and has a low capacity. Most endocytic pathways include lysosomes, where a variety of macromolecules can be degraded. If substances, however, enter by caveolae-mediated endocytosis, they may also be delivered to the endoplasmatic reticulum and to the Golgi apparatus, thereby avoiding degradation in lysosomes. ${ }^{156}$

In addition to transcellular transport, NPs can use the paracellular route to pass epithelial monolayers. Opening of the tight junctions by NPs may present an option for drug delivery across the blood-brain barrier but surface charge appears not to play the most important role. Although cationic albumin particles were able to cross this barrier, tight junctions remained intact. ${ }^{157}$ Studies using dendrimers of different sizes with cationic and anionic charge also suggest that

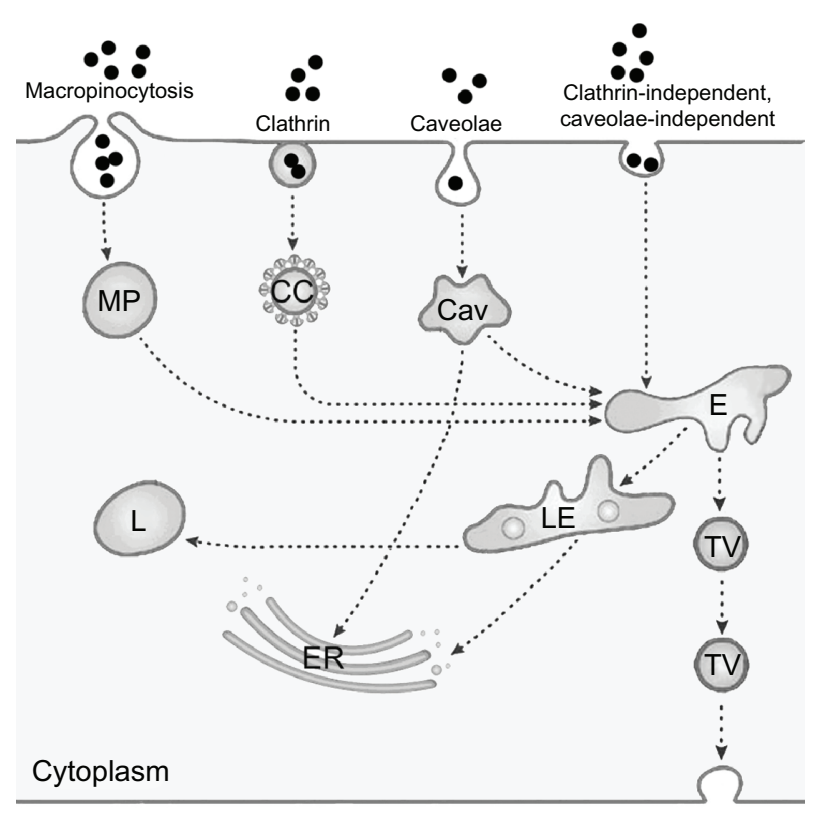

Figure 2 Simplified representation of active uptake mechanisms in nonphagocytic cells Notes: Nanoparticle $(\bullet)$ uptake has been evaluated mainly according to macropinocytosis, represented here as only one route, through macropinosome (MP), clathrin-mediated uptake by clathrin-coated pits (CC), and caveolae-dependent uptake by caveosomes (Cav). Uptake by clathrin-independent caveolae-independent endocytosis, which includes flotillin-, Arf6-, Cdc42-, and RhoA-dependent uptake, is also presented as only one route. Fluid-phase endocytosis, which mainly uses the clathrin-coated pits, is not depicted as a separate route. All pathways deliver their content to endosomes (E), late endosomes (LE) and lysosomes (L); the content of caveolosomes may also be delivered to the endoplasmic reticulum (ER) and the Golgi apparatus. Vesicular transport through the cell occurs through transcytotic vesicles (TV). () 2012, Elsevier. Reproduced with permission from Fröhlich E, Roblegg E. Models for oral uptake of nanoparticles in consumer products. Toxicology. 2012;29I(I-3):8. ${ }^{179}$ 
(large) size is more relevant for opening of tight junctions than surface charge. ${ }^{158}$

Table 2 presents an overview of studies on surfacedependent particle uptake and shows that no general rules have been identified so far. When positively and negatively charged chitosan and poly(lactic acid) particles were compared in the same study, both types of particles used the same (clathrin-mediated) uptake mechanism. ${ }^{159,160}$ Quantum dots can be ingested by clathrin and clathrin-independent caveolae-independent endocytosis. ${ }^{173,174}$ Controverse findings were also reported for cationic polystyrene NPs. Clathrin-mediated ${ }^{175}$, macropinocytototic ${ }^{177}$ and caveolaedependent ${ }^{178}$ routes were described. Plain polystyrene NPs used clathrin-independent endocytosis, whereas positively charged NPs are taken up via clathrin-coated vesicles. ${ }^{175}$ The authors also showed that upon inhibition of the clathrin-mediated uptake, plain NPs were ingested by macropinocytosis as an alternative route. ${ }^{119}$ The influence of size is obvious in the uptake of $24 \mathrm{~nm}$ and $43 \mathrm{~nm}$ anionic polystyrene particles: the smaller particles were taken up by the clathrin-independent caveolae-independent route, whereas the larger ones were ingested by clathrin-mediated endocytosis. ${ }^{176}$ Cell-specific differences also play a role: cationic polystyrene particles were taken up by LAMP-1positive endosomes in the macrophage cell line RAW 264.7 and by caveolae in BEAS-2 cells. ${ }^{162}$ Similar differences were also reported for dendrimers, which were taken up by clathrin-mediated endocytosis in Caco- 2 cells ${ }^{163}$ and by macropinocytosis in A549 cells. ${ }^{164}$ Foster et al reported very

Table 2 Routes of endocytic uptake in nonphagocytic cells

\begin{tabular}{llll}
\hline Particle & Charge & Uptake route & References \\
\hline Quantum dots & Anionic & Clathrin & 173 \\
& Anionic & $\begin{array}{l}\text { Clathrin-independent, } \\
\text { caveolae-independent }\end{array}$ & 174 \\
& & Clathin & 119 \\
& Anionic & Clathrin & 119 \\
& Plain & Macropinocytosis & 175 \\
& Cationic & Clathrin & 175 \\
& Plain & Clathrin-independent & 176 \\
& Anionic & Clathrin (43 nm) & 176 \\
& & Clathrin-independent, & \\
& & caveolae-independent & \\
& & (24 nm) & 177 \\
Chitosan & Cationic & Macropinocytosis & 178 \\
& & Caveolin & 159 \\
& Anionic & Clathrin & 159 \\
& Cationic & Clathrin & 129,160 \\
& Cationic & Clathrin & 160 \\
& Anionic & Clathrin, clathrin- & \\
\hline
\end{tabular}

different rates of particle uptake in the respiratory cell lines A459 and Calu-3. ${ }^{165}$ For the interpretation of these data, problems related to working with uptake inhibitors have to be taken into account. This includes inhibition of more than one route due to low specificity of the inhibitors, uptake by compensatory mechanisms when one route is blocked, alterations of plasma-membrane proteins, disruption of the cortical actin cytoskeleton, and inhibition of vesicle trafficking, etc. ${ }^{166}$

The cell-specific expression of endocytic routes may explain the observed differences in the endocytic routes used, in the amount of particle uptake, and in the velocity of this uptake. It is, for instance, known that smooth-muscle cells, fibroblasts, adipocytes, and endothelial cells have an incredible amount of caveolae, ${ }^{167}$ and therefore preferentially use this route. This leads not only to a different intracellular localization but also to different velocity of uptake. The clathrin-mediated pathway is faster than the clathrin-independent caveolin-independent uptake, ${ }^{160}$ and therefore particles using this route accumulate faster in cells. Asati et al propose to exploit differences in the uptake routes between normal and tumor cells to develop cytostatic NP-based drugs. ${ }^{75}$

Not only cell entry by different uptake routes but also the escape of cationic particles from the endosomal-lysosomal system could explain the charge-dependent differences in the intracellular localization of anionic PLGA and mesoporous and chitosan particles. ${ }^{129,130,168}$

The predictive value of the aforementioned surface charge-dependent cellular studies is currently not clear. For chemicals, a large multicentre evaluation study identified a rather good correlation $\left(R^{2}=0.77\right)$ between $\mathrm{IC}_{50}$ values in cytotoxicity screening assays and human acute poisoning with various chemicals. ${ }^{169}$ For NPs, few comparative data are available, which suggests a low predictive value for inhalation exposure ${ }^{170}$ and a good correlation for parenteral exposure. ${ }^{171}$

\section{Conclusions}

Cationic surface charge for most NPs correlates with higher cellular uptake and greater cytotoxicity in nonphagocytic cells. Cationic NPs appear to cause plasma-membrane disruption to a greater extent and anionic NPs apoptosis. Anionic NPs are better ingested and act more cytotoxically in phagocytic cells. The presence of serum appears to reduce NP uptake in nonphagocytic cells, but increases it in phagocytic cells. The differences between phagocytic and nonphagocytic cells have to be taken into account in the design of medical NPs. 


\section{Acknowledgments}

Financial support by the Austrian Research Science Grant P22576-B18 is gratefully acknowledged. The author thanks Gabriella Salas for English-language editing.

\section{Disclosure}

The author reports no conflicts of interest in this work.

\section{References}

1. El Ouahabi A, Thiry M, Pector V, Fuks R, Ruysschaert JM, Vandenbranden M. The role of endosome destabilizing activity in the gene transfer process mediated by cationic lipids. FEBS Lett. 1997;414(2):187-192.

2. Xu Y, Szoka FC Jr. Mechanism of DNA release from cationic liposome/DNA complexes used in cell transfection. Biochemistry. 1996;35(18):5616-5623.

3. Nafee N, Schneider M, Schaefer UF, Lehr CM. Relevance of the colloidal stability of chitosan/PLGA nanoparticles on their cytotoxicity profile. Int J Pharm. 2009;381(2):130-139.

4. Agashe HB, Dutta T, Garg M, Jain NK. Investigations on the toxicological profile of functionalized fifth-generation poly (propylene imine) dendrimer. J Pharm Pharmacol. 2006;58(11):1491-1498.

5. Dutta T, Garg M, Jain NK. Poly(propyleneimine) dendrimer and dendrosome mediated genetic immunization against hepatitis B. Vaccine. 2008;26(27-28):3389-3394.

6. Al-Rawi M, Diabate S, Weiss C. Uptake and intracellular localization of submicron and nano-sized $\mathrm{SiO}(2)$ particles in HeLa cells. Arch Toxicol. 2011;85(7):813-826

7. Albers CE, Hofstetter W, Siebenrock KA, Landmann R, Klenke FM. In vitro cytotoxicity of silver nanoparticles on osteoblasts and osteoclasts at antibacterial concentrations. Nanotoxicology. Epub October 21, 2011.

8. Fröhlich E, Kueznik T, Samberger C, Roblegg E, Wrighton C, Pieber TR. Size-dependent effects of nanoparticles on the activity of cytochrome P450 isoenzymes. Toxicol Appl Pharmacol. 2010;242(3):326-332.

9. Fröhlich E, Meindl C, Roblegg E, Griesbacher A, Pieber TR. Cytotoxicity of nanoparticles is influenced by size, proliferation and embryonic origin of the cells used for testing. Nanotoxicology. 2012;6(4):424-423.

10. Fröhlich E, Samberger C, Kueznik T, et al. Cytotoxicity of nanoparticles independent from oxidative stress. J Toxicol Sci. 2009;34(4): 363-375.

11. He Q, Zhang Z, Gao Y, Shi J, Li Y. Intracellular localization and cytotoxicity of spherical mesoporous silica nano- and microparticles. Small. 2009;5(23):2722-2729.

12. Lin W, Huang YW, Zhou XD, Ma Y. In vitro toxicity of silica nanoparticles in human lung cancer cells. Toxicol Appl Pharmacol. 2006;217(3):252-259.

13. Nair S, Sasidharan A, Divya Rani VV, Menon D, Manzoor K, Raina S Role of size scale of $\mathrm{ZnO}$ nanoparticles and microparticles on toxicity toward bacteria and osteoblast cancer cells. J Mater Sci Mater Med. 2009;20 Suppl 1:S235-S241.

14. Patil G, Khan MI, Patel DK, Sultana S, Prasad R, Ahmad I. Evaluation of cytotoxic, oxidative stress, proinflammatory and genotoxic responses of micro- and nano-particles of dolomite on human lung epithelial cells A(549). Environ Toxicol Pharmacol. 2012;34(2):436-445.

15. Pietruska JR, Liu X, Smith A, et al. Bioavailability, intracellular mobilization of nickel, and HIF-1alpha activation in human lung epithelial cells exposed to metallic nickel and nickel oxide nanoparticles. Toxicol Sci. 2011;124(1):138-148.

16. Lovric J, Bazzi HS, Cuie Y, Fortin GR, Winnik FM, Maysinger D. Differences in subcellular distribution and toxicity of green and red emitting CdTe quantum dots. J Mol Med. 2005;83(5):377-385.
17. Zhang Y, Yu W, Jiang X, Lv K, Sun S, Zhang F. Analysis of the cytotoxicity of differentially sized titanium dioxide nanoparticles in murine MC3T3-E1 preosteoblasts. J Mater Sci. 2011;22(8):1933-1945.

18. Cha KE, Myung H. Cytotoxic effects of nanoparticles assessed in vitro and in vivo. J Microbiol Biotechnol. 2007;17(9):1573-1578.

19. Yin H, Too HP, Chow GM. The effects of particle size and surface coating on the cytotoxicity of nickel ferrite. Biomaterials. 2005;26(29): 5818-5826.

20. Okuda-Shimazaki J, Takaku S, Kanehira K, Sonezaki S, Taniguchi A. Effects of titanium dioxide nanoparticle aggregate size on gene expression. Int J Mol Sci. 2010;11(6):2383-2392.

21. Chong CS, Cao M, Wong WW, et al. Enhancement of T helper type 1 immune responses against hepatitis B virus core antigen by PLGA nanoparticle vaccine delivery. J Control Release. 2005;102(1):85-99.

22. Morishige T, Yoshioka Y, Inakura H, et al. Cytotoxicity of amorphous silica particles against macrophage-like THP-1 cells depends on particle-size and surface properties. Pharmazie. 2010;65(8): 596-599.

23. Lankoff A, Sandberg WJ, Wegierek-Ciuk A, et al. The effect of agglomeration state of silver and titanium dioxide nanoparticles on cellular response of HepG2, A549 and THP-1 cells. Toxicol Lett. 2012;208(3):197-213.

24. Katsnelson BA, Degtyareva TD, Minigalieva II, et al. Subchronic systemic toxicity and bioaccumulation of $\mathrm{Fe} 3 \mathrm{O} 4$ nano- and microparticles following repeated intraperitoneal administration to rats. Int J Toxicol. 2011;30(1):59-68.

25. Raju HB, Hu Y, Vedula A, Dubovy SR, Goldberg JL. Evaluation of magnetic micro- and nanoparticle toxicity to ocular tissues. PloS One. 2011;6(5):e17452.

26. Poland CA, Duffin R, Kinloch I, et al. Carbon nanotubes introduced into the abdominal cavity of mice show asbestos-like pathogenicity in a pilot study. Nat Nanotechnol. 2008;3(7):423-428.

27. Takagi A, Hirose A, Nishimura T, et al. Induction of mesothelioma in $\mathrm{p} 53+/-$ mouse by intraperitoneal application of multi-wall carbon nanotube. J Toxicol Sci. 2008;33(1):105-116.

28. Onuma K, Sato Y, Ogawara S, et al. Nano-scaled particles of titanium dioxide convert benign mouse fibrosarcoma cells into aggressive tumor cells. Am J Pathol. 2009;175(5):2171-2183.

29. Schaeublin NM, Braydich-Stolle LK, Schrand AM, et al. Surface charge of gold nanoparticles mediates mechanism of toxicity. Nanoscale. 2011;3(2):410-420.

30. Baek M, Kim IS, Yu J, Chung HE, Choy JH, Choi SJ. Effect of different forms of anionic nanoclays on cytotoxicity. J Nanosci Nanotechnol. 2011;11(2):1803-1806.

31. Bhattacharjee S, de Haan LH, Evers NM, et al. Role of surface charge and oxidative stress in cytotoxicity of organic monolayer-coated silicon nanoparticles towards macrophage NR8383 cells. Part Fibre Toxicol. 2010;7:25.

32. Goodman CM, McCusker CD, Yilmaz T, Rotello VM. Toxicity of gold nanoparticles functionalized with cationic and anionic side chains. Bioconjug Chem. 2004;15(4):897-900.

33. Oh WK, Kim S, Choi M, et al. Cellular uptake, cytotoxicity, and innate immune response of silica-titania hollow nanoparticles based on size and surface functionality. ACS Nano. 2010;4(9):5301-5313.

34. Ruizendaal L, Bhattacharjee S, Pournazari K, et al. Synthesis and cytotoxicity of silicon nanoparticles with covalently attached organic monolayers. Nanotoxicology. 2009;3(4):339-347.

35. Naha PC, Davoren M, Lyng FM, Byrne HJ. Reactive oxygen species (ROS) induced cytokine production and cytotoxicity of PAMAM dendrimers in J774A.1 cells. Toxicol Appl Pharmacol. 2010;246(1-2):91-99.

36. McNerny DQ, Leroueil PR, Baker JR. Understanding specific and nonspecific toxicities: a requirement for the development of dendrimer-based pharmaceuticals. Nanomed Nanobiotechnol. 2010;2(3):249-259.

37. Chauhan AS, Diwan PV, Jain NK, Tomalia DA. Unexpected in vivo anti-inflammatory activity observed for simple, surface functionalized poly(amidoamine) dendrimers. Biomacromolecules. 2009;10(5): 1195-1202. 
38. Mura S, Hillaireau H, Nicolas J, et al. Influence of surface charge on the potential toxicity of PLGA nanoparticles towards Calu-3 cells. Int J Nanomedicine. 2011;6:2591-2605.

39. Yu T, Malugin A, Ghandehari H. Impact of silica nanoparticle design on cellular toxicity and hemolytic activity. ACS Nano. 2011;5(7): 5717-5728.

40. Luo X, Feng M, Pan S, Wen Y, Zhang W, Wu C. Charge shielding effects on gene delivery of polyethylenimine/DNA complexes: PEGylation and phospholipid coating. J Mater Sci Mater Med. 2012; 23(7):1685-1695.

41. Corpe W. Attachment of Marine Bacteria to Solid Surfaces. New York: Academic Press; 1970:1

42. Tomita Y, Rikimaru-Kaneko A, Hashiguchi K, Shirotake S. Effect of anionic and cationic n-butylcyanoacrylate nanoparticles on NO and cytokine production in Raw264.7 cells. Immunopharmacol Immunotoxicol. 2011;33(4):730-737.

43. Hoskins C, Wang L, Cheng WP, Cuschieri A. Dilemmas in the reliable estimation of the in-vitro cell viability in magnetic nanoparticle engineering: which tests and what protocols? Nanoscale Res Lett. 2012;7:77.

44. Chung YI, Kim JC, Kim YH, et al. The effect of surface functionalization of PLGA nanoparticles by heparin- or chitosan-conjugated Pluronic on tumor targeting. J Control Release. 2010;143(3):374-382.

45. Panessa-Warren B, Warren J, Wong S, Misewich J. Biological cellular response to carbon nanoparticle toxicity. J Phys Condens Matter. 2006;18(33):S2185.

46. Ryabchikova E, Mazurkova N, Shikina N, Ismagilov Z. The crystalline forms of titanium dioxide nanoparticles affect their interactions with individual cells. J Med Chem Biol Radiol Def. 2010:8.

47. Wang T, Bai J, Jiang X, Nienhaus GU. Cellular uptake of nanoparticles by membrane penetration: a study combining confocal microscopy with FTIR spectroelectrochemistry. ACS Nano. 2012;6(2):1251-1259.

48. Draeger A, Monastyrskaya K, Babiychuk EB. Plasma membrane repair and cellular damage control: the annexin survival kit. Biochem Pharmacol. 2011;81(6):703-712.

49. Mellgren RL. A new twist on plasma membrane repair. Commun Integr Biol. 2011;4(2):198-200.

50. de Planque MR, Aghdaei S, Roose T, Morgan H. Electrophysiological characterization of membrane disruption by nanoparticles. ACS Nano. 2011;5(5):3599-3606.

51. Mu Q, Hondow NS, Krzemiski L, Brown AP, Jeuken LJ, Routledge MN. Mechanism of cellular uptake of genotoxic silica nanoparticles. Part Fibre Toxicol. 2012;9(1):29.

52. Lin J, Zhang H, Chen Z, Zheng Y. Penetration of lipid membranes by gold nanoparticles: insights into cellular uptake, cytotoxicity, and their relationship. ACS Nano. 2010;4(9):5421-5429.

53. Lin JQ, Zheng YG, Zhang HW, Chen Z. A simulation study on nanoscale holes generated by gold nanoparticles on negative lipid bilayers. Langmuir. 2011;27(13):8323-8332.

54. Hong S, Hessler J, Banaszak Holl M, Leroueil P, Mecke A, Orr B. Physical interactions of nanoparticles with biological membranes: the observation of nanoscale hole formation. Chem Health Saf. 2006;13(3): 16-20.

55. Mecke A, Majoros IJ, Patri AK, Baker JR Jr, Holl MM, Orr BG. Lipid bilayer disruption by polycationic polymers: the roles of size and chemical functional group. Langmuir. 2005;21(23):10348-10354.

56. Mecke A, Uppuluri S, Sassanella TM, et al. Direct observation of lipid bilayer disruption by poly(amidoamine) dendrimers. Chem Phys Lipids. 2004;132(1):3-14.

57. Klotz L, Sies H. Cellular Generation of Oxidants: Relation to Oxidative Stress. Weinheim: Wiley; 2009.

58. Brown DM, Hutchison L, Donaldson K, Stone V. The effects of PM10 particles and oxidative stress on macrophages and lung epithelial cells: modulating effects of calcium-signaling antagonists. Am J Physiol. 2007;292(6):L1444-L1451.

59. Peuschel H, Sydlik U, Haendeler J, et al. c-Src-mediated activation of Erk1/2 is a reaction of epithelial cells to carbon nanoparticle treatment and may be a target for a molecular preventive strategy. Biol Chem. 2010;391(11):1327-1332.
60. Sydlik U, Bierhals K, Soufi M, Abel J, Schins RP, Unfried K. Ultrafine carbon particles induce apoptosis and proliferation in rat lung epithelial cells via specific signaling pathways both using EGF-R. Am J Physiol Lung Cell Mol Physiol. 2006;291(4):L725-L733.

61. Jiang W, Kim BY, Rutka JT, Chan WC. Nanoparticle-mediated cellular response is size-dependent. Nat Nanotechnol. 2008;3(3):145-150.

62. Unfried K, Sydlik U, Bierhals K, Weissenberg A, Abel J. Carbon nanoparticle-induced lung epithelial cell proliferation is mediated by receptor-dependent Akt activation. Am J Physiol Lung Cell Mol Physiol. 2008;294(2):L358-L367.

63. Lovric J, Cho SJ, Winnik FM, Maysinger D. Unmodified cadmium telluride quantum dots induce reactive oxygen species formation leading to multiple organelle damage and cell death. Chem Biol. 2005;12(11):1227-1234.

64. Chen L, Yokel RA, Hennig B, Toborek M. Manufactured aluminum oxide nanoparticles decrease expression of tight junction proteins in brain vasculature. J Neuroimmune Pharmacol. 2008;3(4):286-295.

65. Freyre-Fonseca V, Delgado-Buenrostro NL, Gutierrez-Cirlos EB, et al. Titanium dioxide nanoparticles impair lung mitochondrial function. Toxicol Lett. 2011;202(2):111-119.

66. Teodoro JS, Simoes AM, Duarte FV, et al. Assessment of the toxicity of silver nanoparticles in vitro: a mitochondrial perspective. Toxicol in Vitro. 2011;25(3):664-670.

67. AshaRani PV, Low Kah Mun G, Hande MP, Valiyaveettil S. Cytotoxicity and genotoxicity of silver nanoparticles in human cells. ACS Nano. 2009;3(2):279-290.

68. Piao MJ, Kang KA, Lee IK, et al. Silver nanoparticles induce oxidative cell damage in human liver cells through inhibition of reduced glutathione and induction of mitochondria-involved apoptosis. Toxicol Lett. 2011;201(1):92-100.

69. Bexiga MG, Varela JA, Wang F, et al. Cationic nanoparticles induce caspase 3-, 7- and 9-mediated cytotoxicity in a human astrocytoma cell line. Nanotoxicology. 2011;5(4):557-567.

70. Baird SK, Kurz T, Brunk UT. Metallothionein protects against oxidative stress-induced lysosomal destabilization. Biochem J. 2006;394(Pt 1): 275-283.

71. Soenen S, Rivera-Gil P, Montenegro J, Parak W, De Smedt S, Braeckmans K. Cellular toxicity of inorganic nanoparticles: common aspects and guidelines for improved nanotoxicity evaluation. Nanotoday. 2011;6(5):446-465.

72. Funnell WR, Maysinger D. Three-dimensional reconstruction of cell nuclei, internalized quantum dots and sites of lipid peroxidation. J Nanobiotechnol. 2006;4(10):10.

73. Thibodeau MS, Giardina C, Knecht DA, Helble J, Hubbard AK. Silica-induced apoptosis in mouse alveolar macrophages is initiated by lysosomal enzyme activity. Toxicol Sci. 2004;80(1):34-48.

74. Nel AE, Madler L, Velegol D, et al. Understanding biophysicochemical interactions at the nano-bio interface. Nat Mater. 2009;8(7): $543-557$.

75. Asati A, Santra S, Kaittanis C, Perez JM. Surface-charge-dependent cell localization and cytotoxicity of cerium oxide nanoparticles. ACS Nano. 2010;4(9):5321-5331.

76. Johnson-Lyles DN, Peifley K, Lockett S, et al. Fullerenol cytotoxicity in kidney cells is associated with cytoskeleton disruption, autophagic vacuole accumulation, and mitochondrial dysfunction. Toxicol Appl Pharmacol. 2010;248(3):249-258.

77. Li JJ, Hartono D, Ong CN, Bay BH, Yung LY. Autophagy and oxidative stress associated with gold nanoparticles. Biomaterials. 2010;31(23):5996-6003.

78. Khan MI, Mohammad A, Patil G, Naqvi SA, Chauhan LK, Ahmad I. Induction of ROS, mitochondrial damage and autophagy in lung epithelial cancer cells by iron oxide nanoparticles. Biomaterials. 2012;33(5): 1477-1488

79. Stern ST, Zolnik BS, McLeland CB, Clogston J, Zheng J, McNeil SE. Induction of autophagy in porcine kidney cells by quantum dots: a common cellular response to nanomaterials? Toxicol Sci. 2008;106(1): 140-152. 
80. Eidi $\mathrm{H}$, Joubert $\mathrm{O}$, Nemos $\mathrm{C}$, et al. Drug delivery by polymeric nanoparticles induces autophagy in macrophages. Int J Pharm. 2012;422(1-2): 495-503.

81. Vercauteren D, Deschout H, Remaut K, et al. Dynamic colocalization microscopy to characterize intracellular trafficking of nanomedicines. ACS Nano. 2011;5(10):7874-7884.

82. Li C, Liu H, Sun Y, et al. PAMAM nanoparticles promote acute lung injury by inducing autophagic cell death through the Akt-TSC2-mTOR signaling pathway. J Mol Cell Biol. 2009;1(1):37-45.

83. Boyoglu C, Boyoglu-Barnum S, Soni S, et al. The intracellular co-localizations of different size of gold nanoparticles. In: NSTI, editor. Nanotechnology 2011: Bio Sensors, Instruments, Medical, Environment and Energy. CRC Press; 2012;3:489-492.

84. Adam SA. The nuclear pore complex. Genome Biol. 2001;2(9): REVIEWS0007.

85. Peters R. Translocation through the nuclear pore complex: selectivity and speed by reduction-of-dimensionality. Traffic. 2005;6(5):421-427.

86. Nitin N, LaConte L, Rhee WJ, Bao G. Tat peptide is capable of importing large nanoparticles across nuclear membrane in digitonin permeabilized cells. Ann Biomed Eng. 2009;37(10):2018-2027.

87. Nabeshi H, Yoshikawa T, Arimori A, et al. Effect of surface properties of silica nanoparticles on their cytotoxicity and cellular distribution in murine macrophages. Nanoscale Res Lett. 2011;6(1):93.

88. Kamata H, Zinchenko A, Murata S. Effects of cationic and anionic nanoparticles on the stability of the secondary structure of DNA. Colloid Polymer Sci. 2011;289(12):1329-1335.

89. Zinchenko AA, Luckel F, Yoshikawa K. Transcription of giant DNA complexed with cationic nanoparticles as a simple model of chromatin Biophys J. 2007;92(4):1318-1325.

90. Chen M, von Mikecz A. Formation of nucleoplasmic protein aggregates impairs nuclear function in response to $\mathrm{SiO}_{2}$ nanoparticles. Exp Cell Res. 2005;305(1):51-62.

91. Li N, Ma L, Wang J, et al. Interaction between nano-anatase $\mathrm{TiO}_{2}$ and liver DNA from mice in vivo. Nanoscale Res Lett. 2009;5(1): $108-115$.

92. Liu Y, Li W, Lao F, et al. Intracellular dynamics of cationic and anionic polystyrene nanoparticles without direct interaction with mitotic spindle and chromosomes. Biomaterials. 2011;32(32): 8291-8303

93. Lynch I, Dawson KA. Protein-nanoparticle interactions. Nanotoday. 2008;3(1-2):40-47

94. Gheshlaghi ZN, Riazi GH, Ahmadian S, Ghafari M, Mahinpour R. Toxicity and interaction of titanium dioxide nanoparticles with microtubule protein. Acta Biochim Biophys Sin. 2008;40(9): 777-782.

95. Linse S, Cabaleiro-Lago C, Xue WF, et al. Nucleation of protein fibrillation by nanoparticles. Proc Natl Acad Sci U SA. 2007;104(21): 8691-8696.

96. Makarova EG, Gordon RY, Podolski IY. Fullerene C60 prevents neurotoxicity induced by intrahippocampal microinjection of amyloid-beta peptide. J Nanosci Nanotechnol. 2012;12(1):119-126.

97. Cabaleiro-Lago C, Quinlan-Pluck F, Lynch I, et al. Inhibition of amyloid beta protein fibrillation by polymeric nanoparticles. $\mathrm{J} \mathrm{Am} \mathrm{Chem}$ Soc. 2008;130(46):15437-15443.

98. Yoo SI, Yang M, Brender JR, et al. Inhibition of amyloid peptide fibrillation by inorganic nanoparticles: functional similarities with proteins. Angew Chem Int Ed Engl. 2011;50(22):5110-5115.

99. Goldberg DS, Ghandehari H, Swaan PW. Cellular entry of G3.5 poly (amido amine) dendrimers by clathrin- and dynamin-dependent endocytosis promotes tight junctional opening in intestinal epithelia. Pharm Res. 2010;27(8):1547-1557.

100. Coyuco JC, Liu Y, Tan BJ, Chiu GN. Functionalized carbon nanomaterials: exploring the interactions with Caco-2 cells for potential oral drug delivery. Int J Nanomedicine. 2011;6:2253-2263.

101. Vllasaliu D, Exposito-Harris R, Heras A, et al. Tight junction modulation by chitosan nanoparticles: comparison with chitosan solution. Int J Pharm. 2010;400(1-2):183-193.
102. Roger E, Lagarce F, Garcion E, Benoit JP. Lipid nanocarriers improve paclitaxel transport throughout human intestinal epithelial cells by using vesicle-mediated transcytosis. J Control Release. 2009;140(2): 174-181.

103. Sheikpranbabu S, Kalishwaralal K, Lee KJ, Vaidyanathan R, Eom SH, Gurunathan S. The inhibition of advanced glycation end-products-induced retinal vascular permeability by silver nanoparticles. Biomaterials. 2010; 31(8):2260-2271.

104. Petushkov A, Intra J, Graham JB, Larsen SC, Salem AK. Effect of crystal size and surface functionalization on the cytotoxicity of silicalite-1 nanoparticles. Chem Res Toxicol. 2009;22(7):1359-1368.

105. Baier G, Costa C, Zeller A, et al. BSA adsorption on differently charged polystyrene nanoparticles using isothermal titration calorimetry and the influence on cellular uptake. Macromol Biosci. 2011;11(5):628-638.

106. Petri-Fink A, Steitz B, Finka A, Salaklang J, Hofmann H. Effect of cell media on polymer coated superparamagnetic iron oxide nanoparticles (SPIONs): colloidal stability, cytotoxicity, and cellular uptake studies. Eur J Pharm Biopharm. 2008;68(1):129-137.

107. Clift MJ, Bhattacharjee S, Brown DM, Stone V. The effects of serum on the toxicity of manufactured nanoparticles. Toxicol Lett. 2010; 198(3):358-365.

108. Rogers WJ, Basu P. Factors regulating macrophage endocytosis of nanoparticles: implications for targeted magnetic resonance plaque imaging. Atherosclerosis. 2005;178(1):67-73.

109. Chithrani BD, Ghazani AA, Chan WC. Determining the size and shape dependence of gold nanoparticle uptake into mammalian cells. Nano Lett. 2006;6(4):662-668.

110. Gao H, Shi W, Freund LB. Mechanics of receptor-mediated endocytosis. Proc Natl Acad Sci U S A. 2005;102(27):9469-9474.

111. Lu F, Wu SH, Hung Y, Mou CY. Size effect on cell uptake in wellsuspended, uniform mesoporous silica nanoparticles. Small. 2009; 5(12):1408-1413.

112. Wang SH, Lee CW, Chiou A, Wei PK. Size-dependent endocytosis of gold nanoparticles studied by three-dimensional mapping of plasmonic scattering images. J Nanobiotechnol. 2010;8:33.

113. Win KY, Feng SS. Effects of particle size and surface coating on cellular uptake of polymeric nanoparticles for oral delivery of anticancer drugs. Biomaterials. 2005;26(15):2713-2722.

114. Champion JA, Walker A, Mitragotri S. Role of particle size in phagocytosis of polymeric microspheres. Pharm Res. 2008;25(8): 1815-1821.

115. Raynal I, Prigent P, Peyramaure S, Najid A, Rebuzzi C, Corot C. Macrophage endocytosis of superparamagnetic iron oxide nanoparticles: mechanisms and comparison of ferumoxides and ferumoxtran-10. Invest Radiol. 2004;39(1):56-63.

116. Gonzalez O, Smith RL, Goodman SB. Effect of size, concentration, surface area, and volume of polymethylmethacrylate particles on human macrophages in vitro. J Biomed Mater Res. 1996;30(4): 463-473.

117. Wang H, Wu L, Reinhard BM. Scavenger receptor mediated endocytosis of silver nanoparticles into J774A.1 macrophages is heterogeneous. ACS Nano. 2012;6(8):7122-7132.

118. Yu SS, Lau CM, Thomas SN, et al. Size- and charge-dependent nonspecific uptake of PEGylated nanoparticles by macrophages. Int $J$ Nanomedicine. 2012;7:799-813.

119. Jiang X, Musyanovych A, Rocker C, Landfester K, Mailander V, Nienhaus GU. Specific effects of surface carboxyl groups on anionic polystyrene particles in their interactions with mesenchymal stem cells. Nanoscale. 2011;3(5):2028-2035.

120. Thorek DL, Tsourkas A. Size, charge and concentration dependent uptake of iron oxide particles by non-phagocytic cells. Biomaterials. 2008;29(26):3583-3590.

121. Villanueva A, Canete M, Roca AG, et al. The influence of surface functionalization on the enhanced internalization of magnetic nanoparticles in cancer cells. Nanotechnology. 2009;20(11): 115103. 
122. Brandenberger C, Rothen-Rutishauser B, Muhlfeld C, et al. Effects and uptake of gold nanoparticles deposited at the air-liquid interface of a human epithelial airway model. Toxicol Appl Pharmacol. 2010;242(1):56-65.

123. Chen L, McCrate JM, Lee JC, Li H. The role of surface charge on the uptake and biocompatibility of hydroxyapatite nanoparticles with osteoblast cells. Nanotechnology. 2011;22(10):105708.

124. Cho J, Caruso F. Investigation of the interactions between ligandstabilized gold nanoparticles and polyelectrolyte multilayer films. Chem Mater. 2005;17(17):4547-4553.

125. Marquis BJ, Liu Z, Braun KL, Haynes CL. Investigation of noble metal nanoparticle $\zeta$-potential effects on single-cell exocytosis function in vitro with carbon-fiber microelectrode amperometry. Analyst. 2011;136(17):3478-3486.

126. Lorenz MR, Holzapfel V, Musyanovych A, et al. Uptake of functionalized, fluorescent-labeled polymeric particles in different cell lines and stem cells. Biomaterials. 2006;27(14):2820-2828.

127. Miller CR, Bondurant B, McLean SD, McGovern KA, O’Brien DF. Liposome-cell interactions in vitro: effect of liposome surface charge on the binding and endocytosis of conventional and sterically stabilized liposomes. Biochemistry. 1998;37(37):12875-12883.

128. Ge Y, Zhang Y, Xia J, et al. Effect of surface charge and agglomerate degree of magnetic iron oxide nanoparticles on KB cellular uptake in vitro. Colloids Surf B Biointerfaces. 2009;73(2):294-301.

129. Harush-Frenkel O, Rozentur E, Benita S, Altschuler Y. Surface charge of nanoparticles determines their endocytic and transcytotic pathway in polarized MDCK cells. Biomacromolecules. 2008;9(2): 435-443.

130. Yue ZG, Wei W, Lv PP, et al. Surface charge affects cellular uptake and intracellular trafficking of chitosan-based nanoparticles. Biomacromolecules. 2011;12(7):2440-2446.

131. Mailander V, Landfester K. Interaction of nanoparticles with cells. Biomacromolecules. 2009;10(9):2379-2400.

132. Lunov O, Syrovets T, Loos C, et al. Differential uptake of functionalized polystyrene nanoparticles by human macrophages and a monocytic cell line. ACS Nano. 2011;5(3):1657-1669.

133. Drutz DJ. Intracellular fate of Neisseria gonorrhoeae. In: Brooks G, Gotschlich E, Holmes K, Sawyer W, Young F, editors. Immunobiology of Neisseria gonorrhoeae. Washington: American Society for Microbiology; 1978;1:232-235.

134. Kemp SJ, Thorley AJ, Gorelik J, et al. Immortalization of human alveolar epithelial cells to investigate nanoparticle uptake. Am J Respir Cell Mol Biol. 2008;39(5):591-597.

135. Fazlollahi F, Angelow S, Yacobi NR, et al. Polystyrene nanoparticle trafficking across MDCK-II. Nanomedicine. 2011;7(5):588-594.

136. Jaiswal JK, Mattoussi H, Mauro JM, Simon SM. Long-term multiple color imaging of live cells using quantum dot bioconjugates. Nat Biotechnol. 2003;21(1):47-51.

137. Sakai N, Matsui Y, Nakayama A, Tsuda A, Yoneda M. Functionaldependent and size-dependent uptake of nanoparticles in PC12. J Phys Conf Ser. 2011;304:12049.

138. Duan H, Nie S. Cell-penetrating quantum dots based on multivalent and endosome-disrupting surface coatings. J Am Chem Soc. 2007;129(11): 3333-3338.

139. Ryman-Rasmussen JP, Riviere JE, Monteiro-Riviere NA. Surface coatings determine cytotoxicity and irritation potential of quantum dot nanoparticles in epidermal keratinocytes. J Invest Dermatol. 2007;127(1):143-153.

140. Bu Q, Yan G, Deng P, et al. NMR-based metabonomic study of the sub-acute toxicity of titanium dioxide nanoparticles in rats after oral administration. Nanotechnology. 2010;21(12):125105.

141. Makino K, Yamamoto N, Higuchi K, Harada N, Ohshima H, Terada H. Phagocytic uptake of polystyrene microspheres by alveolar macrophages: effects of the size and surface properties of the microspheres. Colloids Surf B Biointerfaces. 2003;27(1): 33-39.
142. Ehrenberg MS, Friedman AE, Finkelstein JN, Oberdorster G, McGrath JL. The influence of protein adsorption on nanoparticle association with cultured endothelial cells. Biomaterials. 2009;30(4): 603-610.

143. Patil S, Sandberg A, Heckert E, Self W, Seal S. Protein adsorption and cellular uptake of cerium oxide nanoparticles as a function of zeta potential. Biomaterials. 2007;28(31):4600-4607.

144. Ferrati S, Mack A, Chiappini C, et al. Intracellular trafficking of silicon particles and logic-embedded vectors. Nanoscale. 2010;2(8): 1512-1520.

145. Taylor U, Klein S, Petersen S, Kues W, Barcikowski S, Rath D. Nonendosomal cellular uptake of ligand-free, positively charged gold nanoparticles. Cytometry A. 2010;77(5):439-446.

146. Arvizo RR, Miranda OR, Thompson MA, et al. Effect of nanoparticle surface charge at the plasma membrane and beyond. Nano Lett. 2010;10(7):2543-2548.

147. Carney RP, Carney TM, Mueller M, Stellacci F. Dynamic cellular uptake of mixed-monolayer protected nanoparticles. Biointerphases. 2012;7(1-4):17.

148. Li Y, Li X, Li Z, Gao H. Surface-structure-regulated penetration of nanoparticles across a cell membrane. Nanoscale. 2012;4(12): 3768-3775.

149. Verma A, Uzun O, Hu Y, et al. Surface-structure-regulated cellmembrane penetration by monolayer-protected nanoparticles. Nat Mater. 2008;7(7):588-595.

150. Doherty GJ, McMahon HT. Mechanisms of endocytosis. Annu Rev Biochem. 2009;78:857-902.

151. Howes MT, Mayor S, Parton RG. Molecules, mechanisms, and cellular roles of clathrin-independent endocytosis. Curr Opin Cell Biol. 2010;22(4):519-527.

152. Sahay G, Alakhova DY, Kabanov AV. Endocytosis of nanomedicines. J Control Release. 2010;145(3):182-195.

153. Sandvig K, Pust S, Skotland T, van Deurs B. Clathrin-independent endocytosis: mechanisms and function. Curr Opin Cell Biol. 2011; 23(4):413-420.

154. Perez-Martinez FC, Guerra J, Posadas I, Cena V. Barriers to non-viral vector-mediated gene delivery in the nervous system. Pharm Res. 2011;28(8):1843-1858.

155. Khalil IA, Kogure K, Akita H, Harashima H. Uptake pathways and subsequent intracellular trafficking in nonviral gene delivery. Pharmacol Rev. 2006;58(1):32-45.

156. Parton RG. Caveolae meet endosomes: a stable relationship? Dev Cell. 2004;7(4):458-460.

157. Lu W, Tan YZ, Hu KL, Jiang XG. Cationic albumin conjugated pegylated nanoparticle with its transcytosis ability and little toxicity against blood-brain barrier. Int J Pharm. 2005;295(1-2):247-260.

158. Kitchens KM, Kolhatkar RB, Swaan PW, Eddington ND, Ghandehari H. Transport of poly(amidoamine) dendrimers across Caco-2 cell monolayers: influence of size, charge and fluorescent labeling. Pharm Res. 2006;23(12):2818-2826.

159. Zaki NM, Nasti A, Tirelli N. Nanocarriers for cytoplasmic delivery: cellular uptake and intracellular fate of chitosan and hyaluronic acidcoated chitosan nanoparticles in a phagocytic cell model. Macromol Biosci. 2011;11(12):1747-1760.

160. Harush-Frenkel O, Debotton N, Benita S, Altschuler Y. Targeting of nanoparticles to the clathrin-mediated endocytic pathway. Biochem Biophys Res Commun. 2007;353(1):26-32.

161. Iversen T, Frerker N, Sandvig K. Endocytosis and Intracellular Trafficking of Quantum Dot-Ligand Bioconjugates. Hoboken: John Wiley \& Sons; 2010.

162. Migliore L, Coppede F. Environmental-induced oxidative stress in neurodegenerative disorders and aging. Mutat Res. 2009;674(1-2): 73-84.

163. Kitchens KM, Foraker AB, Kolhatkar RB, Swaan PW, Ghandehari H. Endocytosis and interaction of poly (amidoamine) dendrimers with Caco-2 cells. Pharm Res. 2007;24(11):2138-2145. 
164. Perumal OP, Inapagolla R, Kannan S, Kannan RM. The effect of surface functionality on cellular trafficking of dendrimers. Biomaterials. 2008;29(24-25):3469-3476.

165. Foster KA, Yazdanian M, Audus KL. Microparticulate uptake mechanisms of in-vitro cell culture models of the respiratory epithelium. J Pharm Pharmacol. 2001;53(1):57-66.

166. Ivanov A. Pharmacological Inhibition of Endocytotic Pathways: is it Specific Enough to be useful? New York: Humana Press; 2008:40.

167. Parton RG, Simons K. The multiple faces of caveolae. Nat Rev Mol Cell Biol. 2007;8(3):185-194.

168. Chen Y, Chen H, Zhang S, et al. Structure-property relationships in manganese oxide - mesoporous silica nanoparticles used for T1-weighted MRI and simultaneous anti-cancer drug delivery. Biomaterials. 2012;33(7):2388-2398.

169. Clemedson C, Dierickx PJ, Sjostrom M. The prediction of human acute systemic toxicity by the EDIT/MEIC in vitro test battery: the importance of protein binding and of partitioning into lipids. Altern Lab Anim. 2003;31(3):245-256.

170. Kroll A, Pillukat MH, Hahn D, Schnekenburger J. Current in vitro methods in nanoparticle risk assessment: limitations and challenges. Eur J Pharm Biopharm. 2009;72(2):370-377.

171. Li Y, Liu J, Zhong Y, et al. Biocompatibility of Fe(3)O(4)@Au composite magnetic nanoparticles in vitro and in vivo. Int J Nanomedicine. 2011;6:2805-2819.
172. Ledet G, Mandal T. Nanomedicine: emerging therapeutics for the 21st century. US Pharm. 2012;37(3):7-11.

173. Xiao Y, Forry SP, Gao X, Holbrook RD, Telford WG, Tona A Dynamics and mechanisms of quantum dot nanoparticle cellular uptake. J Nanobiotechnol. 2010;8:13.

174. Zhang LW, Monteiro-Riviere NA. Mechanisms of quantum dot nanoparticle cellular uptake. Toxicol Sci. 2009;110(1):138-155.

175. Jiang X, Dausend J, Hafner M, et al. Specific effects of surface amines on polystyrene nanoparticles in their interactions with mesenchymal stem cells. Biomacromolecules. 2010;11(3):748-753.

176. Lai SK, Hida K, Man ST, et al. Privileged delivery of polymer nanoparticles to the perinuclear region of live cells via a nonclathrin, non-degradative pathway. Biomaterials. 2007;28(18): 2876-2884.

177. Dausend J, Musyanovych A, Dass M, et al. Uptake mechanism of oppositely charged fluorescent nanoparticles in HeLa cells. Macromol Biosci. 2008;8(12):1135-1143.

178. Xia T, Kovochich M, Liong M, Zink JI, Nel AE. Cationic polystyrene nanosphere toxicity depends on cell-specific endocytic and mitochondrial injury pathways. ACS Nano. 2008;2(1):85-96.

179. Fröhlich E, Roblegg E. Models for oral uptake of nanoparticles in consumer products. Toxicology. 2012;291(1-3):8.
International Journal of Nanomedicine

\section{Publish your work in this journal}

The International Journal of Nanomedicine is an international, peerreviewed journal focusing on the application of nanotechnology in diagnostics, therapeutics, and drug delivery systems throughout the biomedical field. This journal is indexed on PubMed Central,

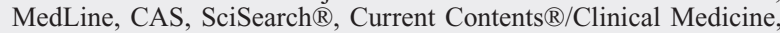

\section{Dovepress}

Journal Citation Reports/Science Edition, EMBase, Scopus and the Elsevier Bibliographic databases. The manuscript management system is completely online and includes a very quick and fair peer-review system, which is all easy to use. Visit http://www.dovepress.com/ testimonials.php to read real quotes from published authors. 